DOI: $10.19195 / 0137-1134.104 .8$

\title{
MICHAŁ STĘPIEŃ
}

Uniwersytet Wrocławski

\section{PRAWO MIĘDZYNARODOWE A UNIWERSALNOŚĆ POJĘCIA SYSTEMU}

J. Wróblewski w jednej ze swoich prac dotyczących teorii prawa stwierdził, że „posługując się zwrotem »system norm《 mamy na względzie zbiór norm, w którym normy są zróżnicowane hierarchicznie, który jest w dostatecznym

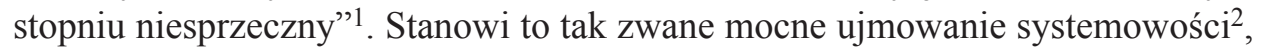
które oprócz walidacji norm w systemie prawa, zakłada również jego niesprzeczność i zupełność. Trudno sobie wyobrazić system prawa, uwzględniający postulat sprawiedliwości formalnej, który byłby wewnętrznie sprzeczny. Przy czym owa „niesprzeczność” na charakter następczy, wynikający z zastosowania reguł kolizyjnych. Postulat sprawiedliwości formalnej wymaga wysokiego stopnia konkluzywności norm. Z kolei postulat sprawiedliwości materialnej oraz efektywności systemu zakłada jego zupełność. Takie rozumienie systemu prawa nawiązuje bezpośrednio do gwarancyjnej funkcji prawa.

Można wyróżniać konkretne systemy prawa oraz systemy-typy. Te ostatnie są systemami pomyślanymi, skonstruowanymi na podstawie wnioskowania indukcyjnego ze względu na konkretne systemy prawa i jako takie mają charakter idealizacyjny. $\mathrm{W}$ takim ujęciu system prawa jest $\mathrm{z}$ założenia niesprzeczny ${ }^{3}$. Jeśli przyjąć a priori, że prawo międzynarodowe publiczne to system prawa, jest to system sui generis nieobjęty przez żaden system-typ. Klasyfikacja systemów konkretnych jest dokonywana na podstawie odpowiedzi na dwa pytania. Po pierwsze: jak należy identyfikować elementy tego systemu (jaka jest reguła uznania)? Po drugie: jakiego rodzaju relacje zachodzą między elementami tego systemu? W przypadku prawa międzynarodowego odpowiedź na te dwa pytania dotyczące właściwości konkretnego systemu prawa nie pozwala na zakwalifikowanie go do znanego systemu-typu. Podstawowymi systemami-typami wykształconymi na

1 K. Opałek, J. Wróblewski, Zagadnienia teorii prawa, Warszawa 1969, s. 78.

2 A. Dyrda, T. Gizbert-Studnicki, Czy systemowość jest konieczna właściwościa prawa?, [w:] „Przegląd Prawa i Administracji” 104. Systemowość Prawa 2016, s. 7-36.

3 K. Opałek, J. Wróblewski, Metodologia: filozofia, teoria prawa, Warszawa 1991, s. 231. 
gruncie komparatystyki prawniczej ${ }^{4}$ są system common law oraz system prawa stanowionego - a zatem systemy prawa krajowego.

Punktem wyjścia do rozważań na temat systemowości prawa międzynarodowego publicznego może być obserwacja, że system prawa (w domyśle: prawa krajowego) jest dziełem człowieka, jego racjonalnej działalności. I chodzi tu nie tylko o system jako kategorię epistemologiczną, ale także jako synonim dla porządku prawnego jako takiego. Prawo nie jest (nie powinno być) chaosem, ale z założenia tworzy się je w wyniku działalności racjonalnej. Inna sprawa, że w przypadku rozwiniętych systemów prawa owa racjonalność stoi pod znakiem zapytania.

Można przewrotnie powiedzieć, że prawo międzynarodowe jest dziełem państw, ale nie człowieka. Na pewnym poziomie ogólności można redukować pojęcie państwa do pojęcia jednostki. Nie jest to jednak możliwe w równym stopniu w przypadku każdego państwa, gdyż ściśle wiąże się z jego ustrojem. W oderwaniu od ustroju państwa redukcja państwa do jednostki sprowadza się do trywialnego twierdzenia, że na państwo składa się ludność. Teza, że prawo międzynarodowe publiczne jest nadal przede wszystkim prawem międzypaństwowym, jest o tyle istotna, iż na jej podstawie można wnioskować o innych właściwościach tego prawa.

Rozwój koncepcji praw człowieka oraz rosnące znaczenie organizacji międzynarodowych (również pozarządowych) powoduje, że niektórzy internacjonaliści opowiadają się zmianą zakresu podmiotowego prawa międzynarodowego publicznego ${ }^{5}$. Zmiana ta powinna się przejawiać w szczególności na upodmiotowieniu jednostki ${ }^{6}$. Takie reductio ad unum może jednak prowadzić do błędu w definiowaniu, z czym wiązałby się taki sposób pojmowania podmiotowości prawa międzynarodowego publicznego. Staje się to oczywiste w szczególności, gdy próbuje się definiować tę podmiotowość przez pryzmat uprawnień. W tym ujęciu należałoby się zastanowić, czy posługiwanie się jednolitą kategorią podmiotów prawa międzynarodowego oznacza przyznanie im chociażby ius contrahendi

${ }^{4}$ K. Opałek, J. Wróblewski, Zagadnienia ..., s. 80.

${ }_{5}$ Zob. chociażby A.A.C. Trindade: The historical recovery of the human person as subject of the law of nations, „Cambridge Journal of International and Comparative Law” 1, 2012, nr 3, s. $12 \mathrm{n}$.

${ }^{6}$ Ibidem. Zgodnie ze stanowiskiem A.A.C. Trindade negacja podmiotowości jednostki stanowi ,zaburzenie” rozwoju prawa międzynarodowego spowodowanego przez przemożny wpływ pozytywizmu prawniczego na teorię prawa w XIX wieku. Należy jednak wyjaśnić, że z punktu widzenia nauki prawa międzynarodowego pozytywizm prawniczy ma nieco inne konotacje niż na gruncie prawa krajowego. Mianowicie w odniesieniu do prawa międzynarodowego pozytywizm jest zazwyczaj rozumiany jako petryfikacja woluntaryzmu, ale w stosunkach między państwami, co wiązało się ściśle z dominującym wówczas modelem ustrojowym. Tym samym upodmiotowienie jednostki w prawie międzynarodowym nie stanowi według Trindade novum, ale powrót do rozumienia państwa jako środka, poprzez który jednostki realizują swoje prawa. Trindade tak wyjaśnia pojęcie państwa: „Created by the human beings themselves, composed by them, for them it exists, for the realization of their common good" (s. 14). Problem w tym, że stanowisko to w sposób dość luźny nawiązuje do praktyki prawa międzynarodowego. 
w stosunkach z państwami w oderwaniu od prawa krajowego. $\mathrm{Z}$ tego względu właściwsze byłoby określanie jednostek mianem beneficjentów prawa międzynarodowego publicznego ${ }^{7}$. Zupełnie inaczej rzecz przedstawia się w przypadku rządowych organizacji międzynarodowych, którym przysługuje ius contrahendi. Istnienie organizacji międzynarodowych jest jednak całkowicie zależne od decyzji państw ${ }^{8}$.

Przyjęty a priori zakres podmiotowy prawa międzynarodowego pozwala wnioskować o podstawowych właściwościach tego prawa. Z suwerenności państw wynika zatem brak wyższej władzy w stosunku do państw. Taką rolę może pełnić wspólnota międzynarodowa. Jeśli uznać Narody Zjednoczone, a w szczególności Radę Bezpieczeństwa NZ, za instytucjonalną emanację wspólnoty międzynarodowej, to po pierwsze ów ,prawodawca" rzadko stanowi prawo, a po drugie jego autorytet jest pośrednio kwestionowany ${ }^{9}$. Brak efektywnej władzy wyższej

7 Należy jednocześnie mieć na uwadze argument oparty na analogii z prawa prywatnego. Mianowicie są systemy prawa krajowego, w których rozróżnia się zdolność prawną oraz zdolność do czynności prawnych. Przykładem tego może być chociażby prawo polskie. Podział ten sprowadza się do rozróżnienia możliwości nabywania prawa i zaciągania zobowiązań oraz możliwości dokonywania czynności prawnych. Podział ów jest wyraźnie widoczny np. w przypadku ubezwłasnowolnienia. Instytucja ubezwłasnowolnienia zakłada jednak istnienie rodzaju pełnomocnictwa (przedstawicielstwa). Tego rodzaju relacja nie zachodzi powszechnie w stosunkach między państwami a jednostkami. M. Huber określił kiedyś prawo międzynarodowe jako ,,a kind of absolute private law at large". Cyt. za H. Lauterpacht, Chapter 8 - Private law sources and analogies of international law, [w:] International Law - Collected Papers - 2. The Law of Peace - Part I - International Law in General, red. E. Lauterpacht, Cambridge 2009, s. 186. Oczywiście, granicą analogii z prawa prywatnego w prawie międzynarodowym będzie specyfika tego ostatniego, co ostatecznie sprowadza się do pytania: jak dalece normy dotyczące jednostek można stosować wobec państw. Na pytanie to należy odpowiedzieć, zanim zastosuje się analogię. Jej stosowanie nie jest tu bowiem oparte na domniemaniu racjonalności ustawodawcy.

8 W praktyce można jednak mówić o daleko posuniętej emancypacji rządowych organizacji międzynarodowych. Przykładem może być UE, w stosunku do której pełnię władzy sprawują Państwa Członkowskie UE (tzw. władcy traktatów, niem.: Herren der Verträge). Zmiana prawa pierwotnego UE, w tym również rozwiązanie UE, wymaga jednak zgody wszystkich Państw Członkowskich. Powoduje to, że rozwiązanie UE, choć możliwe, staje się wysoce nieprawdopodobne. Podobnie rzecz przedstawia się zresztą również np. w przypadku Narodów Zjednoczonych (NZ).

9 Doskonałym przykładem może być sprawa Kadi I (sprawy połączone C-402/05 P i C-415/05 P), gdzie pośrednio oceniono zgodność rezolucji Rady Bezpieczeństwa NZ z podstawowymi prawami człowieka w związku z oceną zgodności z prawem rozporządzenia UE, które tę rezolucję implementowało. Punktem odniesienia dla TS były prawa podstawowe (pkt 326 wyroku). Prawa te TS wywodził zarówno z Karty Praw Podstawowych, jak i z Europejskiej Konwencji Praw Człowieka (dalej: EKPCz) oraz pośrednio ze „wspólnej tradycji konstytucyjnej państw członkowskich" - w tym przypadku chodziło przede wszystkim o zasadę skutecznej ochrony sądowej. Tym niemniej Komisja Europejska (dalej: KE) podniosła zarzut, że przedmiotowa rezolucja Rady Bezpieczeństwa została podjęta ultra vires, nie jest bowiem zbieżna $\mathrm{z}$ art. 3 ust. 1 Karty NZ, zgodnie z którym jednym z celów NZ jest „,popieranie praw człowieka i zachęcanie do ich poszanowania”. TS nie odniósł się jednak do tego argumentu, mimo że podobne stanowisko można znaleźć w wyroku Sądu Pierwszej Instancji (dalej: SPI) będącego przedmiotem kontroli ze strony TS. SPI stwierdził, że ,[...] Karta [NZ] sama zakłada istnienie imperatywnych norm prawa międzynarodowego, 
powoduje, że sankcja ma w przypadku prawa międzynarodowego charakter rozproszony i niezorganizowany - jest to podstawowy zarzut stawiany przez naukę stosunków międzynarodowych prawu międzynarodowemu. Nieefektywność ustawodawcy jest pochodną nieefektywności ustrojodawcy. Postulowana norma uznania dopuszcza bardzo szeroką dowolność w zakresie formy stanowienia prawa. Praktycznym problemem może być odróżnienie traktatu od porozumienia sui generis o charakterze politycznym ${ }^{10}$.

w szczególności podstawowych praw człowieka. W preambule Karty ludy [NZ] oświadczyły, że są zdecydowane »przywrócić wiarę w podstawowe prawa człowieka, w godność i wartość człowieka«. Z rozdziału I [Karty NZ], zatytułowanego »Cele i zasady« wynika, że jednym z celów [NZ] jest zachęcanie do poszanowania praw człowieka i podstawowych wolności”. Ponadto, zdaniem SPI ,[z]godnie z art. 24 ust. 2 Karty [NZ] [...] [u]prawnienia do nakładania sankcji, jakimi dysponuje Rada Bezpieczeństwa [...] muszą być więc wykonywane z poszanowaniem prawa międzynarodowego, a w szczególności celów i zasad [NZ]". Związanie UE rezolucją Rady Bezpieczeństwa NZ jest wynikiem tego, że wszystkie państwa członkowskie UE są obecnie członkami NZ. Podobna sytuacja miała miejsce w przypadku relacji między WE a GATT. Formalnie WE nie była członkiem GATT (obecnie UE jest członkiem WTO), tym niemniej nie przeszkadzało to WE brać udział w negocjacji w ramach GATT. Wynikało to z faktu, że wszystkie państwa członkowskie UE były jednocześnie członkami GATT. Zob. C. Mik, Powierzenie Unii Europejskiej władzy przez państwa członkowskie i jego podstawowe konsekwencje prawne, [w:] Suwerenność i ponadnarodowość a integracja europejska, red. J. Kranz, Warszawa 2006, s. 105. Czy, odwołując się do zasady nemo plus iuris, można powiedzieć, że kompetencja UE jako pochodna kompetencji państw członkowskich może poza te kompetencje państw członkowskich wykraczać? Zdecydowanie nie. Kompetencje państw członkowskich do pewnego stopnia określa norma wyrażona w art. 103 Karty NZ. W takim razie w tym przypadku państwa członkowskie odmówiły kolektywnie zastosowania się do rezolucji Rady Bezpieczeństwa NZ wydanej na podstawie rozdziału VII Karty NZ działając poprzez wspólny organ sądowy. Zob. chociażby P. Hilpold, EU law and UN law in conflict: the Kadi case, „Max Planck Yearbook of United Nations Law" 13, 2009, s. 20.

10 Zob. A. Aust, Modem Treaty Law and Practice, Cambdridge 2007, s. 25-27 oraz M. Fitzmaurice, The identification and character of treaties and treaty obligations between states in international law, „British Yearbook of International Law” 73, 2002, s. 141. Interesującym przykładem niejasności co do zakresu pojęcia umowy międzynarodowej jest tak zwane memorandum of understanding (dalej MOU, pol.: „memorandum porozumienia”, ,protokół ustaleń”). Tak na przykład w formie MOU zawarto w 2007 roku porozumienie między UE a Radą Europy. Również w formie MOU zawarto chociażby porozumienie między UE a Chińską Republika Ludową dotyczące wywozu niektórych chińskich wyrobów włókienniczych i odzieżowych do UE. Żadne z tych MOU nie zostało opublikowane w Dzienniku Urzędowym UE. MOU między UE a CHRL zostało jedynie wspomniane w pkt 6 preambuły Rozporządzenia KE nr 1084/2005 (Dz. Urz. UE [2005] L 177/19). Innym poważnym problemem dotyczącym traktatów jest dość sporna kwestia zastrzeżeń niedopuszczalnych. Jest to zagadnienie szczególnie doniosłe w przypadku traktatów dotyczących praw człowieka. Zob. M. Stępień, Zastrzeżenia do traktatów praw człowieka: świadectwo praworząności czy bezprawia? O swobodzie wyboru standardów praw czlowieka, [w:] Wpływ standardów międzynarodowych na rozwój demokracji i ochronę praw człowieka, t. 1, red. J. Jaskiernia, Warszawa 2013, s. 170 n. Problem sprowadza się do tego, że zgodnie z Konwencją wiedeńską o prawie traktatów z 1969 r. (dalej: KWPT) można zasadniczo domniemywać swobodę składania zastrzeżeń. Swoboda ta jest jednak ograniczona wymogiem, by złożone zastrzeżenie nie godziło w cel ani w przedmiot umowy. Problem nie występuje w przypadku umów pozornie wielostronnych, tj. takich, które tworzą prawa i obowiązki w stosunkach dwustronnych jak np. Konwencja wiedeńska 
Brak ustrojodawcy powoduje, że nadal w prawie międzynarodowym duże znaczenie odgrywa zwyczaj. Co prawda powszechne prawo międzynarodowe zostało w dużej mierze skodyfikowane, tym niemniej prawo zwyczajowe pełni obecnie dogodny środek uznawania aktów soft law za prawo obowiązujące (systemowo ${ }^{11}$. To jednak rozwiązanie budzące wiele kontrowersji i przede wszystkim sporne. Wspólnota międzynarodowa jest $\mathrm{w}$ dużym stopnia redukowalna do stosunków dwustronnych ${ }^{12}$. Znaczącym wyjątkiem są traktaty dotyczące ochrony praw człowieka, prawa humanitarnego, ochrony środowiska oraz konstytuujące organizacje międzynarodowe. Brak władzy wyższej odnosi się nie tylko do kwestii tworzenia prawa, ale także rozstrzygania sporów. Rola sądownictwa jest ograniczona, co wynika $\mathrm{z}$ faktu, że sądownictwo to nie jest przymusowe. O ile można negować koncepcje woluntarystyczne prawa międzynarodowego w zakresie jego

o stosunkach dyplomatycznych z 1961 roku czy też Konwencja wiedeńska o stosunkach konsularnych z 1963 roku. W przypadku umów prawdziwie wielostronnych (ustanawiających między stronami uprawienia i zobowiązania erga omnes), jak właśnie traktaty dotyczące ochrony praw człowieka, złożenie sprzeciwów przez niektóre ze stron umowy już jednak nie wystarcza, gdyż sprzeciwy mają zastosowanie między państwem składającym zastrzeżenie a składającym sprzeciw. Zresztą praktyka pokazuje, że sprzeciwy do zastrzeżeń składa jedynie niewielka część stron, a to oznacza, że pozostałe w sposób milczący wyrażają swoją akceptację (zgodnie z art. 20 ust. 5 KWPT). Sprzeciwy do zastrzeżeń nie są jednak skuteczne erga omnes wobec pozostałych stron, a ich skutki zgodnie z KWPT wywierają skutki w stosunkach dwustronnych (art. 20 ust. $4 \mathrm{~b}$ oraz art. 21 ust. 3 KWPT). Nawet jeśli założyć, że można w ramach jakiejś procedury stwierdzić autorytatywnie ze skutkiem erga omnes nieskuteczność danego zastrzeżenia, pojawia się kolejny problem. Mianowicie czy oznacza to nieważność zastrzeżenia w oderwaniu czy też w połączeniu ze zgodą na związanie się traktatem przez stronę. Jeśli uznać, że nieważność zastrzeżenia oznacza również nieważność wyrażenia zgody (przecież zastrzeżenia składane są w sposób ostateczny razem z aktem wyrażenia zgody na związanie się traktatem), oznacza to, że państwo (lub ewentualnie inny podmiot prawa międzynarodowego), które złożyło niedopuszczalne zastrzeżenie do danego traktatu, przestaje być jego stroną. Jest zatem całkowicie zwolnione z obowiązków przewidzianych tym traktatem. W przypadku traktatów dotyczących ochrony praw człowieka może to oznaczać, że na przykład obniży się standard ochrony praw jednostek podlegających jurysdykcji takiego państwa.

$11 \mathrm{~W}$ ogóle daje się zresztą zauważyć zmiana podejścia do normatywności prawa międzynarodowego. Znaczącym przykładem jest kwestia formy kodyfikacji w zakresie odpowiedzialności państw. Zob. Report of the International Law Commission, Fifty-third session (23 April - 1 June and 2 July - 10 August 2001, General Assembly Official Records, Fifty-sixth session, Supplement No.10 (A/56/10), pkt 64, s. 39. Znaczący jest następujący fragment: ,a convention was not strictly necessary since the draft articles adopted on second reading were bound to be influential, just as the existing text had been widely cited and relied on by the International Court and other tribunals". Jak widać stanowisko to sprowadza się do finistycznego ujęcia prawa, które bliskie jest nauce prawa międzynarodowego. Zaskakiwać może jednak podsumowanie kilkudziesięciu lat pracy Komisji Prawa Międzynarodowego rezolucją Zgromadzenia Ogólnego NZ (Resolution 56/83 adopted by the General Assembly, A/RES/56/83) którą Zgromadzenie to „,commends [articles] to the attention of Governments".

12 Zob. B. Simma, From bilateralism to community interest in international law, ,Recueil des Cours” 250, 1994, s. 229-233. Doskonale to stanowisko ilustruje dyskusja zarysowana w przypisie 24 na s. 131. 
tworzenia, o tyle jest to wyraźnie kontrfaktyczne w zakresie kompetencji sądów międzynarodowych ${ }^{13}$.

Ponieważ prawo międzynarodowe dotyczy stosunków pomiędzy państwami i jest tworzone przez państwa, można się zastanawiać, na ile takie pojęcie jak „system prawa międzynarodowego" koresponduje z potrzebami praktyki międzynarodowej. Znaczące jest tu zjawisko postępującej fragmentaryzacji prawa międzynarodowego. Polega ona tym, że państwa tworzą tak zwane self-contained régimes. Prawo międzynarodowe, w odróżnieniu od prawa krajowego nie dysponuje rozwiniętą wspólnotą komunikacyjną. W tym przypadku przejawia się to tym, że maleje rola „powszechnego" prawa międzynarodowego. Fragmentaryzację prawa międzynarodowego można w uproszczeniu zredukować do relacji między lex generalis a lex specialis, zakładając, że self-contained régime to właśnie lex specialis $^{14}$. Problem pojawia się natomiast w przypadku kolizji norm pochodzących $\mathrm{z}$ różnych self-contained régimes. Prawo traktatów (którego kodyfikację stanowi KWPT) proponuje w takim przypadku chronologiczną zasadę kolizyjną. Rzecz w tym, że jej zastosowanie jest możliwe pod warunkiem, że normy, między którymi zaszła kolizja, zostały ustanowione przez te same podmioty (art. 30 ust. 3

13 Tak na przykład Międzynarodowy Trybunał Sprawiedliwości (dalej: MTS) jako organ rozstrzygający spory między państwami przywiązuje do tego bardzo dużą wagę. Spory rozstrzygane przez MTS nie mają powtarzalnej podstawy jurysdykcji, jak ma to miejsce w przypadku ETPCz. Każde postępowanie sporne przed MTS rozpoczyna się od wykazania jego jurysdykcji.

14 Koncepcja self-contained régime początkowo odnosiła się do reguł rozsądzania, co na gruncie prawa międzynarodowego sprowadzało się do zagadnień odpowiedzialności międzynarodowej. Zob. B. Simma, Self-contained regimes, „Netherlands Yearbook of International Law” XVI, 1985, s. 112-113. W nauce prawa międzynarodowego podkreśla się, że stosowanie norm stanowiących taki régime nie jest wyłączenie kwestią ich treści, ale również sposobu ich ustanowienia: właśnie faktu, że stanowią one część owego régime. Jest to zatem argumentacja w najwyższych stopniu oparta na pojmowaniu prawa przez pryzmat jego systemowości. Przykładem tego rodzaju stanowiska może być odniesienie koncepcji self-contained régime do „porządków prawnych” organizacji międzynarodowych, takich jak WTO czy UE. W przypadku UE prawo wtórne ma ostatecznie charakter aktów wykonawczych w stosunku do prawa pierwotnego, które jako takie stanowi prawo międzynarodowe. Podobnie jednak jak system prawny, self-contained régime potrzebuje czegoś na kształt normy podstawowej, pewnego przyjętego a priori założenia. To założenie to zwykle wynik pewnej praktyki i jest powszechnie akceptowane, a także niekiedy wiąże się z przedmiotem regulacji (najsłabszą postacią self-contained régime jest jego wyróżnienie przez przedmiot regulacji, co upodabnia go znacząco do gałęzi prawa). T.C. Hartley, rozważając autonomię prawa UE, posługuje się więc przykładem konstytucji Kanady, która została ustanowiona jako ustawa parlamentu westminsterskiego z 1867 roku. Podkreśla, że nie można z tego faktu wnioskować, by prawo kanadyjskie mogło być obecnie oceniane pod kątem jego zgodności z prawem brytyjskim. Zob. T.C. Hartley, The constitutional foundations of the european union, „Law Quarterly Review” 117, 2001, s. 229-230. Ostatecznym argumentem przemawiającym za absurdalnością tezy o możliwości oceny prawa kanadyjskiego pod względem jego zgodności z prawem brytyjskim jest faktyczna niezależność prawa kanadyjskiego, która przejawia się właśnie w długotrwałej praktyce jego stosowania, co wyraża się między innymi przez fakt, że Kanada jako państwo (co nie budzi wątpliwości na gruncie prawa międzynarodowego) musi posiadać suwerenną władzę. 
oraz art. 40 ust. 4 KWPT ${ }^{15}$. Natomiast w przypadku kolizji wielostronnych umów międzynarodowych sytuacja jednolitości stron występuje niezwykle rzadko. Dlatego kolizje norm będą rozstrzygane w stosunkach dwustronnych między zainteresowanymi państwami, czyli między tymi, których prawa i obowiązki określają te same normy (art. 30 ust. 4 KWPT). To rozwiązanie nie może jednak mieć zastosowania w przypadku prawdziwie wielostronnych umów międzynarodowych, czyli takich, które nie tworzą praw i obowiązków w stosunkach dwustronnych, ale wielostronnych, a zatem zarówno te prawa i te obowiązki są w założeniu skuteczne erga omnes. Przykładem tego rodzaju umów są traktaty dotyczące ochrony prawa człowieka ${ }^{16}$ czy też ochrony środowiska. Każda ze stron umowy wielostronnej może zawierać umowy, które mogą stać w kolizji z zawartą już przez to państwo umową wielostronną ${ }^{17}$. Taka sytuacja nie musi być wcale wynikiem celowego działania: kolizja norm ma przede wszystkim charakter konkretny, a nie abstrakcyjny, i dochodzi do niej w procesie stosowania prawa. Nie należy natomiast do rzadkości sytuacja, gdy dany podmiot prawa międzynarodowego jest związany dwiema różnymi umowami z dwoma innymi podmiotami. Wywiązanie się z jednej z nich powoduje naruszenie drugiej. $Z$ punktu widzenia pozostałych stron tych umów ów argument nie ma jednak znaczenia. Umowa, której są stroną, nie jest wykonywana, a strona naruszająca umowę powołuje się na swoje zobowiązania

15 Nieco inaczej rzecz się ma w przypadku porozumień inter se. Trudno jednak bronić stanowisko, że self-contained régime to porozumienia inter se. Po pierwsze, przemawia za tym całkowicie inna skala regulacji. Po drugie, porozumienia inter se są regulowane przez KWPT z założeniem, że takie porozumienie zawarły niektóre strony umowy zawartej wcześniej, które postanowiły w stosunkach między sobą odejść od tej wcześniejszej umowy. Nie będą jednak porozumieniami inter se umowy z państwami trzecimi, a więc takimi, które nie są stronami wcześniejszej umowy.

16 Europejska Komisja Praw Człowieka w sprawie Austria v. Włochy (Application No. 788/60) ujęła to następująco: „In becoming a Party to the Convention, a State undertakes, vis-à-vis the other High Contracting Parties, to secure the rights and freedoms defined in Section I [of the European Convention on Human Rights] to every person within its jurisdiction, regardless of his or her nationality or status [...]; it undertakes to secure these rights and freedoms not only to its own nationals and those of other High Contracting Parties but also to nationals of States not parties to the Convention and to stateless persons [...]. The obligations undertaken by the High Contracting Parties in the Convention are essentially of an objective character, being designed rather to protect the fundamental rights of individual human beings from infringement by any of the High Contracting Parties than to create subjective and reciprocal rights for the High Contracting Parties themselves".

$17 \mathrm{~W}$ tym zakresie dokonała się w prawie międzynarodowym znacząca zmiana. Zob. J.B. Mus, Conflicts between treaties in international law, „Netherlands International Law Review” 45, 1998, s. 230. E. de Vattel argumentował, że „[m]onarcha, związany już przez umowę, nie może zawierać innych, które by były z nią sprzeczne. Sprawy, co do których się zobowiązał, już od niego nie zależą". Cyt. za E. de Vattel, Prawo narodów czyli zasady prawa naturalnego zastosowane do postępowania i spraw narodów i monarchów, przeł. B. Winiarski, tytuł oryginału: Droit des gens; ou, Principes de la loi naturelle appliqués à la conduite et aux affaires des nations et des souverains, Warszawa 1958, s. 435. Posługując się niedoskonałą analogią do prawa prywatnego, można powiedzieć, że umowy międzynarodowe należą do sfery zobowiązań i jako takie wywierają skutki przede wszystkim inter partes. 
w stosunku do kogoś innego. J. Klabbers wskazuje, że w takim przypadku zastosowanie ma tak zwana reguła polityczna ${ }^{18}$. Jest to jednak rozwiązanie ad hoc i jako takie nie stanowi reguły kolizyjnej, lecz próbę legitymizacji naruszenia zaciągniętych zobowiązań. Pozostaje postulować, aby stosowanie reguły politycznej było oparte na spójnych założeniach aksjologicznych, co jednak w stosunkach międzynarodowych zdaje się być wysoce nieprawdopodobne. Innym rozwiązaniem byłoby stworzenie jakiegoś mechanizmu koordynacji, co sprowadzałoby się do ustanowienia organu rozstrzygającego tego typu kwestie w ramach czegoś na kształt postępowania wstępnego. Oczywiście, sprowadza się to do ustanowienia w prawie międzynarodowym civitas maximus. Tego rodzaju postulat, biorąc pod uwagę stan rozwoju wspólnoty międzynarodowej, jest wysoce nierealny. Nie ma jednak przeszkód, by początkowo nie mogło objąć to tylko części wspólnoty międzynarodowej ${ }^{19}$. Na podobnej zasadzie stronami Statutu Rzymskiego (tj. traktatu ustanawiającego Międzynarodowy Trybunał Karny) ${ }^{20}$ jest prawie sto trzydzieści państw, podczas gdy obecnie NZ liczy sto dziewięćdziesiąt trzech członków ${ }^{21}$. Nie przeszkadza to jednak twierdzić, że Status ten stanowi ,a substantial supplement to the UN Charter"22. Paradoksalnie remedium na postępującą fragmentaryzację i niespójność prawa międzynarodowego jest skorzystanie z możliwości, które daje fragmentaryzacja międzynarodowego. Tak właśnie rozwija i zmienia się jednak prawo międzynarodowe.

Organy rozstrzygania sporów funkcjonujące w ramach self-contained régime są jednak zwolnione z takich dylematów związanych z kolizją norm. Przyczyna tego jest bardzo prosta. Funkcjonują one na podstawie określonych umów i to właśnie z tych umów wynika ich kompetencja ${ }^{23}$. Jeśli zatem pojawia się kolizja norm

18 J. Klabbers, Treaty Conflict and the European Union, Cambridge 2009, s. 88 n.

19 M. Stępień, Jednolitość stosowania prawa międzynarodowego - postępowanie wstępne przed Międzynarodowym Trybunałem Sprawiedliwości, [w:] Aksjologia współczesnego prawa międzynarodowego, red. A. Wnukiewicz-Kozłowska, Wrocław 2011.

20 Dalej: MTK.

21 Do końca 2002 roku, w którym Statut Rzymski wszedł w życie, jego stronami zostało 87 państw.

22 B. Krzan, The relationship between the international criminal court and the international court of justice, [w:] Juridictional Competition of International Courts and Tribunals, red. B.Krzan, Wrocław 2012, s. 165. Za tezą tę przemawia preambuła Statutu Rzymskiego ustanawiającego MTK, a w szczególności pkt 7 i 9 preambuły, zgodnie z którymi cele MTK są zbieżne z celami NZ, a sam MTK ,związany z systemem” NZ.

${ }^{23}$ Zagadnienie kompetencji ma bardzo duże znaczenie w przypadku jakiegokolwiek rodzaju sądów międzynarodowych z tej prostej przyczyny, że nie jest to kompetencja domniemana. Widać to szczególnie w przypadku MTS, który, rozstrzygając spór, wydaje dwa wyroki, z których pierwszy dotyczy właśnie jurysdykcji. Dopiero jeśli MTS przesądzi o swojej jurysdykcji w danym sporze, to rozstrzyga sprawę co do istoty. W przypadku Trybunału Sprawiedliwości UE (dalej: TSUE) pojawia się z kolei pojęcie jurysdykcji wyłącznej (wynikającej z art. 344 TFUE). Sprowadza się ona do tego, że państwa członkowskie nie mogą wieść sporów prawnych dotyczących prawa UE przed organami innymi niż Instytucje UE. Rozważając zakres prawa UE, podkreśla się bardzo często, że obejmuje 
danego self-contained régime oraz z normami powszechnego prawa międzynarodowego ${ }^{24}$ lub innego self-contained régime - organy te stosują po prostu normy tego self-contained régime, w ramach którego funkcjonują 25 . To nieco upodabnia je do krajowych sądów konstytucyjnych. Przykładem takiej postawy jest opinia TS w sprawie zawarcia przez UE porozumienia o przystąpieniu UE do EKPCz ${ }^{26}$. Trybunał Sprawiedliwości stwierdził, że zawarcie tego porozumienia przez UE nie jest zgodne z traktatami konstytuującymi UE, gdyż ,przystąpienie [UE] do EKPC, tak jak przewidziano w projekcie porozumienia, może godzić w szczególne cechy prawa $[\mathrm{UE}]$ i autonomię prawa $[\mathrm{UE}]^{\prime 27}$. Ponadto „,[z]godnie z utrwalonym orzecznictwem Trybunału umowa międzynarodowa nie może naruszać struktury kompetencyjnej określonej w traktatach [UE] i tym samym autonomii systemu prawnego [UE], nad której przestrzeganiem Trybunał czuwa" ${ }^{28}$. Dla organów sądowych stanowiących instytucję self-contained régimes rozstrzygnięcie kolizji nie stanowi problemu i nie wymaga odwołania się do reguły politycznej29. Wystar-

ono również międzynarodowe prawo zwyczajowe. Tym niemniej stosowanie międzynarodowego prawa zwyczajowego przez TSUE w trakcie wykonywania jego funkcji orzeczniczej nie oznacza, że TSUE ma jurysdykcję wyłączną w zakresie stosowania międzynarodowego prawa zwyczajowego między członkami UE. Zob. T. Thienel, The exclusive jurisdiction of the European Court of Justice and its effect on other international courts and tribunals, [w:] Jurisdictional Competition..., Wrocław 2012, s. 204.

${ }^{24}$ Nie można z góry wykluczyć takiej kolizji. Mówienie o odrębności self-contained régime nie oznacza, że w jego ramach nie ma mowy o zastosowaniu powszechnego prawa międzynarodowego. Ostatecznie normy takiego régime stanowią wobec powszechnego prawa międzynarodowego lex specialis. W każdym razie o ile państwa mogą w stosunkach między sobą odejść od powszechnego prawa międzynarodowego, jest to jednak ograniczone właśnie powszechnym prawem międzynarodowym. W szczególności nie ma mowy o naruszeniu ius cogens. J. Pauwelyn ujmuje to następująco , in their treaty relations states can »contract out « of one, more or, in theory, all rules of international law (other than those of jus cogens), but they cannot contract out of the system of international law”, by zaraz dodać, że ,[t] he prohibition on setting up a treaty regime outside international law can, to some extent, be compared to the prohibition on a limited number of individuals under domestic law setting up their own »state-within-the state«". Cyt. za J. Pauwelyn, Conflict of Norms in Public International Law - How WTO Law Relates to other Rules of International Law, Cambridge 2003, s. 37.

25 Stanowi to rozwinięcie normy określonej w art. 5 KWPT. W trakcie prac nad KWPT delegat amerykański M.S. McDougal zauważył, że art. 5 oznacza ni mniej ni więcej, że ,states desiring to evade the Convention's basic provisions would only need to establish an international organization to meet their requirements". Cyt. za M.E. Viliger, Commentary on the 1969 Vienna Convention on the law of Treaties, Leiden 2009, s. 118. M.E. Viliger, przywołując stanowisko M.S. McDougala, podnosi jednak, że sytuacja ta jest po prostu wysoce nieprawdopodobna, a to $\mathrm{z}$ tego prostego względu, że państwa mogą przecież w każdej chwili zawrzeć umowę inter se w stosunku do KWPT.

26 Opinia 2/13, postępowanie wszczęte na podstawie art. 218 ust. 1 TFUE.

27 Pkt 200 opinii.

28 Pkt 201 opinii.

29 Przykładem może być również system WTO (a w przeszłości GATT), który również uważany jest za self-contained régime. Zgodnie z art. 1 Dispute Settlement Understanding podstawą rozstrzygania sporów w ramach WTO są umowy zawarte w jej ramach z uwzględnieniem reguł 
czy poprzestać na hierarchicznej regule kolizyjnej. Zakładając, że pierwszeństwo (przede wszystkim w aspekcie derogacji) przysługuje normom konstytuującym dany régime, taka postawa jest oparta na postulacie pewności prawa. Państwa, czy też organizacje międzynarodowe, uczestniczące w różnych self-contained régimes nie ma mają tego komfortu.

Podstawowa wada reguły politycznej to jej wysoka nieprzewidywalność, sprowadzająca się do uznaniowości. Uwzględnianie w procesie rozstrzygania kolizji argumentów dotyczących aksjologii prawa międzynarodowego nie musi być wcale konkluzywne. Podstawy aksjologiczne prawa międzynarodowego są wysoce sporne. Widać to w przypadku „zacięcia aksjologicznego” w Karcie NZ, czyli konfliktu między poszanowaniem integralności państw z jednej strony oraz samostanowieniem narodów z drugiej ${ }^{30}$. Rozstrzyganie kolizji norm w ramach self-contained régime jest o wiele prostsze. Jednocześnie, rozstrzyganie kolizji między normami pochodzącymi z różnych self-contained régimes nie jest konluzywne, co znacznie osłabia tezę o systemowym charakterze prawa międzynarodowego w mocnym ujęciu.

Za pojmowanie prawa międzynarodowego jako systemu w słabym ujęciu przemawiają następujące argumenty. Po pierwsze, postuluje się jedność reguł walidacyjnych (przede wszystkim jednak w ujęciu negatywnym). Po drugie, poprzez nawiązanie do pojmowania systemu prawa na gruncie czystej teorii prawa, jako normę podstawową wskazuje się zasadę pacta sunt servanda ${ }^{31}$. Rolę taką może pełnić również art. 103 Karty NZ. Po trzecie, istnienie zobowiązań erga omnes zakłada, że członkowie wspólnoty międzynarodowej mają wobec siebie zarówno prawa, jak i obowiązki o charakterze powszechnie obowiązującym. Po czwarte,

wykładni prawa międzynarodowego publicznego (art. 3 ust. 2 DSU). J. Pauwelyn czyni przy tym ciekawe spostrzeżenie. Wskazuje mianowicie, że w pracach nad traktatem ustanawiających WTO, fakt, że ostatecznie wynegocjowane porozumienie będzie częścią prawa międzynarodowego, nie był w pełni uświadomiony. Po części mogło to wynikać z tego, że w negocjacjach brało udział wielu ministrów handlu. W niektórych państwach stanowisko ministra handlu jest oddzielone od stanowiska ministra spraw zagranicznych. Zob. J. Pauwelyn: The role of public international law in the WTO: how far can we go?, „American Journal of International Law” 95, 2001, s. 538. Argument ten podnosi również P.J. Kuijper. Zob. P.J. Kuijper, The law of GATT as a special field of international law - ignorance, further refinement or self-contained system of international law?, „Netherlands Yearbook of International Law" XXV, 1994, s. 251-252.

30 R. Kwiecień, Teoria i filozofia prawa międzynarodowego - problemy wybrane, Warszawa 2011, s. 167.

31 Niezwykle trudno sobie wyobrazić porządek prawny pozbawiony jakiegokolwiek nakazu postępowania zgodnie z prawem. Obowiązek ten pozwala w ogóle odróżnić prawo od innych porządków normatywnych. W przypadku koncepcji normatywistycznej nakaz ten zawiera się w normie podstawowej. Zob. H. Kelsen, Principles of International Law, red. R.W. Tucker, New York 1966, s. 580. Bez tej zasady „,[i]nternational law as well as civil law would be a mere mockery”. Cyt. za B. Cheng, General Principles of Law as Applied by International Courts and Tribunals, Cambridge 1953, s. 113. Zob. także A.T. Guzman, How International Law Works - A Rational Choice Theory, Oxford 2008, s. 135. 
istnienie zasad prawa międzynarodowego zakłada przynajmniej rudymentarną materialną spójność prawa międzynarodowego.

Argument oparty na jednolitości reguł walidacyjnych jest kluczowy. Systemowość prawa presuponuje jego autopojetyczność, a w szczególności jego samodefiniowanie się. Na pewnym poziomie ogólności twierdzenie o istnieniu reguł walidacyjnych prawa międzynarodowego jest bezsporne. Stwierdzenie obowiązywania in concreto stwarza jednak poważne trudności. Nie dość jasny jest podział między umowami międzynarodowymi a porozumieniami politycznymi ${ }^{32}$. Brakuje jednoznacznych reguł określających skutek tak zwanych zastrzeżeń niedopuszczalnych składanych do umów ustanawiających zobowiązania erga omnes. Znacząca rola prawa zwyczajowego powoduje jednak, że reguły walidacyjne prawa międzynarodowego nie obejmują jego znacznej części. Rzecz w tym, że prawo zwyczajowe obowiązuje behawiorystycznie i określenie warunków jego obowiązywania przez normy walidacyjne ma charakter wtórny i co najwyżej porządkujący, względnie stanowi narzędzie poznawcze ${ }^{33}$. Dlatego tak duże znaczenie

32 Rozważając zagadnienie soft law internacjonaliści mówią o soft law w ujęciu formalnym (i w tym znaczeniu termin ten jest zazwyczaj wykorzystywany w prawoznawstwie) oraz w ujęciu materialnym. Przykładem soft law w ujęciu materialnym jest Konwencja ramowa Rady Europy o ochronie mniejszości narodowych (Dz.U. $2000 \mathrm{Nr}$ 22, poz. 209). Konwencja ta nie definiuje podmiotu ochrony, którym jest tu „mniejszość narodowa”. Oznacza to zatem, że decyzja odnośnie do zakresu tej nazwy jest pozostawiona stronom. Zob. Explanatory Report, European Treaty Series - no. 157 (https://rm.coe.int/CoERMPublicCommonSearchServices/ DisplayDCTMContent?documentId=09000016800cb5eb (dostęp:15.09.2016) gdzie w pkt 12 stwierdzono: ,[i]t was decided to adopt a pragmatic approach, based on the recognition that at this stage, it is impossible to arrive at a definition capable of mustering general support of all Council of Europe member States". W tym przypadku było to związane z ułatwieniem zawarcia tej umowy, to jednak oznacza, że jej stosowanie może prowadzić do rozbieżności. Tak więc na trzydzieści dziewięć stron tej Konwencji czternaście złożyło deklaracje interpretacyjne wyjaśniające ich stosunek do terminu „mniejszość narodowa”. Niektóre strony (m.in. Polska) w swojej deklaracji zamieściły klasyczną definicję „mniejszości narodowej”. Ale np. Holandia wyjaśniła, że w jej przypadku Konwencja będzie miała zastosowanie tylko wobec Fryzów. Odnośnie do dyskusji dotyczącej treści reguł walidacyjnych prawa międzynarodowego, czyli w zasadzie jego zakresu zob. M. Koskenniemi, From apology to utopia: The structure of International Legal Argument, Cambridge 2007, s. 182-223.

33 Dotyczy to w ogóle tak zwanych aktów praktyki. W przypadku obowiązywania behawiorystycznego przesłanki obowiązywania nie zależą od tego czy dany akt (konwencjonalny) został dokonany zgodnie z regułami sensu. Akty praktyki nie są zatem objęte w całości przez króla Midasa. Por. H. Kelsen, The Pure Theory of Law, Berkeley 1970, s. 278. Oznacza to, że paradoksalnie nie można rozsądnie dyskutować o przesłankach dla obowiązywania prawa zwyczajowego, odnosząc się do reguł walidacji, takich jak reguła uznania, gdyż ostatecznie norma ta stanowi rodzaj normy zwyczajowej, ma wobec niej zastosowanie kryterium efektywności. H. Kelsen wskazuje jednak: „[no] fact has, by itself, legal effects”. Cyt. H. Kelsen, Principles..., s. 394. H.L.A. Hart wyjaśnia problem obowiązywania reguły uznania następująco: „Reguła ta nie może ani obowiązywać ani też nie obowiązywać, ale jest po prostu akceptowana jako właściwa do stosowania w tym celu". Cyt. za H.L.A. Hart, Pojęcie prawa, przeł. J. Woleński, tytuł oryginału: The Concept of Law, Warszawa 1998, s. 151. J. Raz z kolei wyjaśnia, że istnienie reguły uznania jest „kwestią praktyki społecznej”. Zob. J. Raz: Autorytet Prawa, przeł. P. Maciejko, tytuł oryginału: The Authority of Law - Essays 
przywiązuje się na gruncie prawa międzynarodowego do orzecznictwa sądowego, gdyż to ono stanowi legitymizowany środek rozpoznania, czy w danym przypadku uzasadnione jest mówienie o prawie zwyczajowym i jaka jest treść tego prawa. Można też przyjąć, że obowiązywanie prawa zwyczajowego w stosunkach między państwowych sprowadza się do wielości reguł walidacyjnych ${ }^{34}$. Wielość reguł walidacyjnych nie presuponuje jednak istnienia ,środków umożliwiających rozwiązywanie konfliktów pomiędzy prawami pochodzącymi z różnych źródeł"35.

W kontekście reguł walidacyjnych znacząca jest koncepcja ius cogens. Normy tego rodzaju stanowią negatywne kryterium obowiązywania. Słabością koncepcji ius cogens jest to, że ich treść jest wysoce sporna. Można jednak wskazać normy ius cogens, które nie budzą kontrowersji. Trudno bowiem polemizować $\mathrm{z}$ tezą, że to co stanowi przedmiot zbrodni międzynarodowej, jest jednocześnie normą peremptoryjną. Jeśli bowiem na przykład tortury stanowią czyn karalny na gruncie prawa międzynarodowego ${ }^{36}$, to umowę, zgodnie $\mathrm{z}$ którą strony przyznają sobie wzajemnie uprawnienie do torturowania, należy oczywiście uznać za bezwzględnie nieważną.

W ujęciu pozytywnym za podstawę normatywną prawa międzynarodowego wskazuje się Kartę NZ rozumianą jako konstytucję społeczności międzynarodowej ${ }^{37}$. Argumenty przemawiającym za tym stanowiskiem to następujące właściwości Karty NZ:

uniwersalizm par excellence, trwałość, substancjalna niezmienność, uprawnienie [NZ] do zapewnienia zgodności działań państw nieczłonkowskich z zasadami [Karty NZ] w stopniu koniecznym do osiągnięcia jej głównego celu - utrzymania międzynarodowego pokoju i bezpieczeństwa ([art. 2 ust. $6 \mathrm{KNZ}]$ ) czy wreszcie nadrzędność zobowiązań wynikających z [Karty NZ] nad innymi zobowiązaniami jej stron ([art. 103 Karty NZ] $)^{38}$.

Jako „zasadniczą umowę w prawie międzynarodowym”39 pozwala Kartę NZ określić w szczególności ostatni z przytoczonych argumentów. W dyskusji na ten

on Law and Morality, Warszawa 2000, s. 96. Prawo zwyczajowe obowiązuje więc na podstawie podobnego uzasadnienia co reguly wtórne. Por. D. Lefkowitz, The sources of international law: some philosophical reflections, [w:] The Philosophy of International Law, red. S. Besson, J. Tasioulas, Oxford 2010, s. 199-201. Należy dodać, że wedle H. Kelsena, normy ostateczne prawa międzynarodowego, czy też po prostu norma podstawowa, są zwyczajowe, gdyż nakazują państwom postępować tak, jak postępowały do tej pory. Zob. H. Kelsen, Principles..., s. 564.

34 J. Raz, op. cit., s. 97; D. Lefkowitz, op. cit., s. 198.

35 J. Raz, op. cit., s. 97.

36 Zgodnie z art. 7 ust. 1 Statutu MTK (Dz.U. 2003 Nr 78, poz. 708) tortury stanowią zbrodnię przeciwko ludzkości. Należy jednak również wspomnieć o wcześniejszej Konwencji w sprawie zakazu stosowania tortur oraz innego okrutnego, nieludzkiego lub poniżającego traktowania albo karania z 1984 r. (Dz.U. 1989 Nr 63, poz. 378). Zgodnie z art. 4 i 5 tej Konwencji na stronach ciąży obowiązek typizacji tortur w krajowym prawie karnym oraz regulacji jurysdykcji w tym zakresie na podstawie zasady terytorialności oraz obywatelstwa.

37 R. Kwiecień, op. cit., s. 88 n.

38 Ibidem, s. 88.

39 Ibidem, s. 163. 
temat podnosi się argument, że konstytucja stanowi powiązanie dwóch właściwości: formalnej i materialnej. Formalną właściwością jest nadrzędność norm danej konstytucji nad pozostałymi normami danego systemu, natomiast właściwością materialną byłoby regulowanie „basic rules governing the life of a community" 40 . Wychodząc od tych ogólnych założeń, łatwo dojść do wniosku, że Karta NZ stanowi konstytucję wspólnoty międzynarodowej, a tym samym prawa międzynarodowego jako prawa tej wspólnoty ${ }^{41}$.

Koncepcja zobowiązań erga omnes zakłada odejście od bilateralizmu w prawie międzynarodowym i stanowi bezpośrednie nawiązanie do idei norm ius cogens. Wynika to chociażby z tego, że normy ius cogens z definicji są jednocześnie normami erga omnes ${ }^{42}$. W pewnym sensie koncepcja erga omnes stanowi proceduralne rozwinięcie koncepcji norm ius cogens. O ile w swym założeniu idea norm peremptoryjnych odnosi się do kwestii nieważności umów międzynarodowych, o tyle wyróżnienie norm erga omnes sprowadza się do zagadnień proceduralnych, a więc określenia tego, wobec kogo dany podmiot prawa międzynarodowego jest zobowiązany lub uprawniony. Uprawnienia erga omnes są dość oczywiste, na przykład w zakresie suwerenności terytorialnej. Można tu mówić, przez analogię do prawa prywatnego, o prawie podmiotowym skutecznym erga omnes. W tym przypadku uprawniony jest jednak tylko jeden podmiot. Idea zobowiązań erga omnes zakłada z kolei, że z uprawnienia może skorzystać wiele podmiotów. Jeśli zatem dane państwo będące stroną wielostronnej umowy dotyczącej na przykład ochrony praw człowieka, nie wywiąże się z jakiegoś ciążącego na nim zobowiązania to uprawnionym do dochodzenia wykonania tego zobowiązania będzie każda inna strona tej umowy. Strona, która dochodzi wykonania zobowiązania, nie musi być w sposób szczególny zainteresowana. Tak więc na przykład w przypadku umów dotyczących praw człowieka z żądaniem zaprzestania naruszania umowy nie musi występować wyłącznie ta strona, której obywatelami są pokrzywdzone jednostki. Jest to zresztą tym bardziej uzasadnione, że w przeważającej mierze zobowiązania państw w zakresie ochrony praw człowieka dotyczą sytuacji prawnej ich własnych obywateli. Koncepcja zobowiązań erga omnes jest szczególnie istotna w tych przypadkach, gdy brakuje zinstytucjonalizowanego mechanizmu kontrolnego.

Mimo swojej doniosłości koncepcja erga omnes nie ma jak na razie wpływu na kompetencję sądów międzynarodowych ${ }^{43}$. Widać to wyraźnie w sprawie Timoru Wschodniego, w której Portugalia powołała się na zobowiązanie erga omnes

40 B. Simma, From bilateralism..., s. 260.

41 Ibidem, s. 262.

42 Ibidem, s. 293-294.

43 Tak samo jest zresztą w przypadku sądów krajowych. W tym przypadku sprowadza się to do kwestii immunitetu państwa. Dotychczasowa praktyka nieco rozczarowuje. W zakresie immunitetu cywilnego odnośnie do roszczeń z tytułu tortur znaczący jest wyrok ETPCz w sprawie Al-Adsani przeciwko Wielkiej Brytanii (Application no. 35763/97). Ratio decidendii tego wyroku znajduje 
przeciwko Australii. Spór dotyczył w istocie naruszenia praw człowieka przez Indonezję w stosunku do ludności Timoru Wschodniego. MTS uznał, że nie może rozstrzygnąć sporu co do meritum, ponieważ sprawa dotyczy w istocie praw i obowiązków Indonezji, która nie była stroną postępowania ${ }^{44}$. O ile zatem koncepcja erga omnes rozszerza krąg podmiotów uprawnionych do występowania z roszczeniami w przypadku naruszenia określonych norm prawa międzynarodowego, o tyle nie stanowi jednak per se podstawy kompetencji MTS. To oznacza, że „sąd światowy" nie jest odpowiednim forum dla dochodzenia roszczeń związanych $\mathrm{z}$ naruszeniem zobowiązań erga omnes ${ }^{45}$.

W dyskusji na temat systemowości prawa, a także prawa międzynarodowego należy poruszyć temat więzi materialnych między normami, co na gruncie prawa międzynarodowego sprowadza się przede wszystkim do problematyki ogólnych zasad prawa. Zagadnienie to jest przedmiotem sporego zainteresowania nauki prawa międzynarodowego, szczególnie ze względu na fakt, że zasady prawa odgrywają znaczącą rolę w stosowaniu prawa międzynarodowego. Stała obecność zasad prawa $\mathrm{w}$ dyskursie dotyczącym źródeł prawa międzynarodowego wynika w znacznej części z tego, że ogólne zasady prawa są wymienione, jako podstawa wyrokowania MTS (a wcześniej Stałego Trybunału Sprawiedliwości Międzynarodowej) ${ }^{46}$, obok traktatów i prawa zwyczajowego ${ }^{47}$. Geneza tej regulacji sprowadza się do postulatu zupełności prawa międzynarodowego. Należy dodać, że zupełność jest kluczową właściwością systemów prawnych ${ }^{48}$. W przypadku sądownictwa międzynarodowego postulat zupełności jest określany jako zakaz

ciągle zastosowanie. Widać to w sprawach połączonych Jones i inni przeciwko Wielkiej Brytanii (Applications nos. 34356/06 and 40528/06).

44 Międzynarodowy Trybunał Sprawiedliwości powołał się na tak zwaną zasadę Monetary Gold polegającą na tym, że MTS nie może przesądzać o prawach i obowiązkach państw, które nie wyraziły zgody na udział w danym postępowaniu przed MTS. Jest to uzasadnione tym, że kompetencja MTS nie jest domniemana, a jej podstawę stanowi zgoda państw wiodących spór. Zasada ta została dobitnie wyrażona w wyroku w sprawie Case of the monetary gold removed from Rome in 1943 (Preliminary Question), Judgment of June 15th, 1954, ICJ Reports 1954, s. 32.

45 Nie dotyczy to jednak orzekania w ramach postępowania dotyczącego wydawania opinii doradczych. Widać to wyraźnie w sprawie muru palestyńskiego (Legal Consequences of the Construction of a Wall in the Occupied Palestinian Territory, Advisory Opinion, ICJ Reports, 2004, s. $136 \mathrm{n}$.), w której MTS uznał działania Izraela za niezgodne z prawem międzynarodowym. MTS wydał opinię, mimo że Izrael stanowczo podnosił w pisemnym oświadczeniu złożonym na podstawie art. 66 ust. 2 Statutu MTS, że postępowanie doradcze pełniło w tym przypadku rolę postępowania spornego, a na takie Izrael w żadnej formie nie wyraził zgody. Zob. Letter dated 29 January 2004 from the Deputy Director General and Legal Advisor of the Ministry of Foreign Affairs, together with the Written Statement of the Government of Israel, s. 105-106.

46 Dalej: STSM.

47 Art. 38 ust. 1 Statutu MTS.

48 H. Lauterpacht, Function of Law in the International Community, Oxford 1933, s. 64. H. Lauterpacht argumentuje, że ,[t] there may be gaps in the various manifestations of customary law $[\ldots]$ [t]here are no gaps in the legal system taken as a whole". 
odmowy orzekania w sytuacji non liquet. Zakaz ten stanowi w istocie bardzo stanowczy postulat zupełności kwalifikacyjnej systemu prawa. Zgodnie z tym postulatem na sądzie międzynarodowym ciąży obowiązek merytorycznego rozstrzygnięcia sporu, czyli wyraźne określenie, czy dane roszczenie znajduje czy też nie znajduje oparcia $\mathrm{w}$ prawie międzynarodowym ${ }^{49}$. Wskazanie ogólnych zasad prawa, jako jednej z podstaw orzekania STSM, miało na celu wykluczenie sytuacji non liquet ${ }^{50}$.

Istnienie ogólnych zasad prawa międzynarodowego oznacza istnienie aksjologicznych podstaw tego prawa oraz „rdzenia normatywnego”. R. Kwiecień stwierdza dobitnie, że istnienie ogólnych zasad prawa powszechnego prawa międzynarodowego stanowi ,warunek konieczny istnienia prawa powszechnego jako systemu"51. Należy pamiętać, że nie jest to odwołanie do systemu prawa w ujęciu statycznym. Nie jest bowiem wcale tak, że na podstawie tych zasad można wnioskować o treści wszystkich norm w systemie prawa. Ogólne zasady prawa międzynarodowego stanowią zarówno tak zwane reguły „drugiego rzędu”, jak i reguły „pierwszego rzędu" 52 . Zasady stanowiące reguły „drugiego rzędu” mają charakter konstrukcyjny. Należy do nich między innymi zasada dobrej wiary, pacta sunt servanda czy estoppel. Bez nich nie można by zaciągać zobowiązań, a trudno sobie wyobrazić pozbawiony tego funkcjonujący system prawny. Tym niemniej, o ile zasady prawa odgrywają znaczną rolę w procesie stosowania prawa (zapewniając jego zupełność), o tyle są wysoce niekonkluzywne - kolizje między nimi rzadko daje się rozstrzygać in abstracto.

Dyskusja dotycząca systemowego charakteru prawa międzynarodowego toczy się w cieniu sporu o to, na ile prawa międzynarodowe zasługuje na miano „prawa” we właściwym tego słowa znaczeniu. Pojmowanie prawa międzynarodowego jako prawa stanowi presupozycję stanowiska, że prawo międzynarodowe jest systemem prawa. Należy zauważyć, że pojęcie systemu prawa jest wtórne wobec pojęcia prawa ${ }^{53}$, choć jednocześnie w przypadku obowiązywania syste-

49 Omawiany zakaz stanowi w istocie odpowiednik „nakazu pozytywnego rozstrzygnięcia”, który jest jednak rzadko sformułowany bezpośrednio. Tym niemniej właśnie owym nakazem są uzasadnione wnioskowania prawnicze. System prawny pozbawiony wnioskowań prawniczych nie byłby zupełny, gdyż ostatecznie ,prawo pozytywne zawiera luki”. Cyt. za J. Wróblewski, Modele systemów norm a system prawa, SPE, t. 2, Łódź 1969, s. 45. H. Lauterpacht wyjaśnia, że „nakaz pozytywnego rozstrzygnięcia”, w odróżnieniu od prawa krajowego, nie jest jako taki postulatem prawa międzynarodowego. Dlatego tak istotne było wskazanie ogólnych zasad prawa w art. 38, ust. 1 statutu MTS. Zob. H. Lauterpacht, The Function of Law in the International Community, Oxford 1933, s. 67. B. Cheng ujął to następująco: ,[the draftsmen of the Statute of the Permanent Court of International Justice] reduced to silence the prophets of gloom who assumed that, one day, international adjudication would founder on the rock of non liquet". Cyt. za B. Cheng, op. cit., s. xi.

50 Zob. „Yearbook of International Law Commission” II, 1958, s. 8, gdzie mowa o non liquet w kontekście procedury arbitrażowej.

51 R. Kwiecień, op. cit., s. 87.

52 Ibidem.

53 Takie stanowisko zajmuje chociażby H.L.A. Hart. Zob. H.L.A. Hart, op. cit., s. 314. 
mowego podkreśla się, że normy nie mogą istnieć w oderwaniu od systemu, poza nim. Oznacza to, że przyjęcie, iż w przypadku prawa międzynarodowego można mówić o obowiązywaniem systemowym (nawet w stosunku do części norm, które nawet w sposób arbitralny uważa się na będące prawem międzynarodowym), oznacza jednocześnie przyjęcie, że prawo międzynarodowe jest systemem (przynajmniej w słabym ujęciu). Jeśli jednak istnieje szeroka zgoda, że umowy międzynarodowe czy też prawo zwyczajowe stanowią prawo międzynarodowe, to nawet jeśli niekiedy mogą istnieć kontrowersje in concreto odnośnie do tego czy innego porozumienia zawartego między państwami, to nie podważa to tezy, że można mówić o regule uznania w prawie międzynarodowym. Jest to oczywiście odmienne stanowisko niż to, które zajął H.L.A. Hart w twierdzeniu, że prawo międzynarodowe jest prawem, lecz nie systemem, pozostając zbiorem norm powiązanych treściowo, których to obowiązywanie jest rozstrzygane ad casu. Stanowisko to jest, według autora niniejszej pracy, uzasadnione w stosunku do prawa zwyczajowego. Jako takie stanowi ono część prawa międzynarodowego, za każdym razem obowiązywanie tego rodzaju norm wymaga jednak dowodzenia. Sam fakt, że w danym przypadku ma się do czynienia z normą prawa zwyczajowego wymaga dowiedzenia na podstawie postępowania członków danej społeczności (w tym przypadku społeczności międzynarodowej) ${ }^{54}$. Podobnie zresztą rzecz przedstawia się w przypadku aktów soft law. W obu przykładach dowodzi się rzecz jasna okoliczności należących do sfery bytu: przede wszystkim tego, na ile normy te są bezpośrednio skuteczne w stosunku do ich podmiotów. Tradycyjnie wskazuje się na konieczność wykazania praktyki oraz tak zwanego opinio iuris (które sprowadza się w dużym uproszczeniu do wewnętrznej akceptacji prawa ${ }^{55}$. Inaczej jednak rzecz się przedstawia w przypadku norm traktatowych. Pomijając problematykę otwartej tekstowości definicji traktatu, która jest przedstawiona chociażby w art. 2 KWPT, kryterium skuteczności bezpośredniej jest w stosunku do traktatów odnoszone o wiele rzadziej. To prawda, że na gruncie prawa międzynarodowego wobec traktatów można powołać się na desuetudo, nie jest to jednak wyjątkowa właściwość ani traktatów, ani prawa międzynarodowego jako takiego.

54 Ibidem, s. 152.

55 Jednocześnie nadal dość ugruntowany jest pogląd, że prawo zwyczajowe w ramach prawa międzynarodowego to tacit pactum. Argumentem przemawiającym za tym jest koncepcja persistent objector czyli państwa (podmiotu prawa międzynarodowego), które protestuje, zanim norma zwyczajowa się ostatecznie wykształtuje. Innymi słowy persistent objector godzi w powszechność i jednolitość praktyki. Co ważne, sama koncepcja została w pełni sformułowana w wyroku MTS w sprawie łowisk (Fisheries case, Judgment of December 18 th, 1951, I.C.J. Reports 1951, s. 116). Na s. 139 MTS przedstawił takie argumenty przemawiające za stanowiskiem Norwegii: „The notoriety of the facts, the general toleration of the international community, Great Britain's position in the North Sea, her own interest in the question, and her prolonged abstention would in any case warrant Norway's enforcement of her system against the United Kingdom". Jak widać, liczba relewantnych faktów przy ocenie obowiązywania określonej normy zwyczajowej jest zatem znacząca. To powoduje, że jest to zagadnienie wysoce sporne. 
Należy pamiętać, że zarówno w przypadku desuetudo, jak i tym bardziej „późniejszej praktyki stron", można mówić o swego rodzaju tacit pactum. Moc obowiązująca danej normy traktatowej podlega zazwyczaj dowodzeniu w niewiele większym stopniu niż moc obowiązująca ustawy na przykład w polskim systemie prawnym. To pozwala zatem przyjąć, że prawo międzynarodowe jest systemem przynajmniej w słabym ujęciu.

Brak w prawie międzynarodowym rozwiniętych reguł kolizyjnych podważa tezę o jego mocnej systemowości. Prawo międzynarodowe nie jest konkluzywnie niesprzeczne. Oprócz walidacji obowiązywania oraz zupełności, niesprzeczność stanowi jeden z kluczowych elementów przytoczonego na początku niniejszego opracowania pojęcia systemu prawa. Normy kolizyjne są w przypadku prawa międzynarodowego rozwinięte w stopniu nie dość zadowalającym i powodują, że wybór norm sprzecznych jest w pewnych (i to nierzadkich) przypadkach oparty na regule politycznej. Ściśle wiąże się z tym postępująca fragmentaryzacja prawa międzynarodowego, która oznacza nic innego jak negację systemowego charakteru prawa międzynarodowego.

Dogmatyka prawa międzynarodowego, odwołując się do pojęcia systemu prawa i podkreślając systemowy charakter prawa międzynarodowego, argumentuje w istocie za tym, że prawo międzynarodowe jest prawem we właściwym tego słowa znaczeniu, a nie ,pozytywną moralnością"56. Jest to jednak system rodzajowo odmienny od tego, z którym można mieć do czynienia w przypadku prawa krajowego. Nie chodzi tu wcale o tak fetyszyzowaną sankcję zorganizowaną. Kluczem do systemowości prawa nie jest przecież kwestia sankcji, ale zagadnienie ustalenia norm prawnych mających zastosowanie w danym przypadku. Jeśli zatem kwestia obowiązywania prawa jest pytaniem, to system prawa międzynarodowego nie stanowi na nie wyczerpującej odpowiedzi. Przywiązanie nauki prawa do idei systemowości wynika przede wszystkim z tego, że prawo jako takie (a zatem przede wszystkim krajowe) jest zazwyczaj systemowe, a w ujęciu dogmatyki prawniczej prawo jest systemem ontologicznie. Dlaczego to międzynarodowe prawo nie miałoby być systemem? Dogmatyka prawa międzynarodowego przeciwstawia się nowoczesnej negacji prawa międzynarodowego prezentowanej przez H.L.A. Harta. Stanowisko dogmatyki prawa międzynarodowego odnośnie do systemowości prawa międzynarodowego przypomina nieco stanowisko $\mathrm{H}$. Kelsena, które przyjął w stosunku do problemu sankcji prawa międzynarodowego. Stwierdził mianowicie, że prawo międzynarodowe jest ,prawem” we właściwym tego słowa znaczeniu, gdyż posiada sankcję, którą jest w ostateczności wojna ${ }^{57}$. Podobnego rodzaju argumentem jest ten o systemowym charakterze prawa międzynarodowego. Prawo międzynarodowe to „prawo", ponieważ stanowi system prawa. To prawda, że stanowi to

${ }^{56}$ Być może internacjonaliści zwracają na to zagadnienie tak dużą uwagę, gdyż dla dogmatyki prawa w rozmowie o istocie prawa kluczowe jest zagadnienie norm sankcjonujących. Z tej perspektywy mówienie o „moralności władców” wydaje się właściwsze.

57 H. Kelsen, Principles..., s. 17. 
odwrócone wnioskowanie. Wychodzi jednak z tych założeń, na których opiera się po prostu dogmatyka prawnicza ${ }^{58}$. Problem w tym, że systemowość, o której można mówić w przypadku prawa międzynarodowego, ma słaby, a nie mocny charakter, a zatem nie jest to taki system prawa, jakim zwykle postrzega się prawo krajowe. Nawet tak rozumiana systemowość prawa międzynarodowego stanowi jednak znaczące narzędzie w zakresie rozpoznawania oraz stosowania norm prawa międzynarodowego. Nie stanowi za to odpowiedzi na wszystkie pytania odnośnie do zupełności kwalifikacyjnej prawa międzynarodowego, co najwyżej na część z nich ${ }^{59}$. Jest to jednak dowód na to, że systemowość prawa stanowi dla prawników tak ważną koncepcję, że jest ona przez nich stosowana do prawa pod bardzo wieloma względami różnego od prawa krajowego.

\section{INTERNATIONAL LAW AND THE UNIVERSALITY OF THE CONCEPT OF THE SYSTEM}

\section{Summary}

The key feature of international law is that states are primary subjects of this law. This results in other features of international law like high relevance of customary law, ambiguous meaning of the term "treaty", considerable role of soft law, uncertainty about the effects of reservations to treaties, and above all, the lack of collision rules when two or more treaties bind partly different parties. This all supports the weaker thesis about systemness of international law. The weaker thesis about systemness of international law is not the answer to all questions that can be put in this respect. This is particularly evident in the case of consistency of international law which is seriously jeopardized by the progressive fragmentation. But the conviction of the systemness of international law has also somewhat different purpose than it seems. Namely, it strengthens the argument that international law is the law in the proper sense of the word. It fulfils therefore, to some extent, a persuasive function. International law confronted with domestic law is a kind of so-called "positive morality" for many lawyers. Therefore, the thesis about systemness of international law is so important. For similar reasons, H. Kelsen so firmly stressed that war is a sanction, what justified the view that international law is the law in the proper sense of the word.

58 Z. Pulka, Czy nastapit zmierzch pozytywistycznej koncepcji prawa i prawoznawstwa, [w:] Z zagadnień teorii i filozofii prawa. W poszukiwaniu podstaw prawa, red. A. Sulikowski, Wrocław 2006, s. 150.

59 D. Lefkowitz, op. cit., s. 196. 